\title{
PENDIDIKAN HUKUM PENCEGAHAN TINDAK PIDANA NARKOTIKA DAN DAMPAK NARKOTIKA TERHADAP ANAK
}

\author{
Marlina $^{1}$, Mahmud mulayadi $^{2}$, Liza erwina $^{3}$ \\ ${ }^{123}$ Fakultas Hukum Universitas Sumatera Utara \\ Linafulinsia@yahoo.com
}

\begin{abstract}
ABSTRAK
Maraknya tindak pidana narkotika yang terjadi di masyarakat menimbulkan permasalahan besar karena korbannya tidak hanya orang dewasa akan tetapi juga anak-anak. Tindak pidana narkotika juga terjadi disemua lapisan masyarakat mulai dari kelas ekonomi rendah sampai ke kelas atas baik di kota maupun di desa. Desa Salam Tani Kecamatan Pancur Batu dan Desa Tengan Kecamatan Pancur adalah dua desa yang menjadi mitra dalam pengabdian ini, Di dua desa tersebut permasalahan narkotika merupakan permasalahan yang sangat mengkhawatirkan. Banyak faktor pendukung peredaran narkotika diantaranya, wilayah mitra, mata pencaharian masyarakatnya sebagian buruh sawit dan buruh tani, tingkat penghasilan yang rendah menyebabkan anak tidak terpantau hanya tamat SMA dan SMP sertA tidak memiliki kegiatan.

Metode yang digunakan adalah melakukan pendekatan secara persuasif dan intensif kepada masyarakat, pimpinan pemerintahan desa dan kecamatan, dengan komunikasi ringan dan terstruktur.. Selanjutnya dilakukan pertemuan dalam forum yang formal di balai desanya untuk lebih tegas dan jelas dalam menyampaikan materinya. Penyampaian materi secara ceramah dan tutorial kepada masyarakat guna memberikan pemahaman tentang tindak pidana narkotika dan dampak pengunaannya. Selanjuntya dilakukan diskusi dan wawancara serta mengali permasalahan dan solusi yang diinginkan oleh masyarakat dalam pencegahan tindak pidana narkotika. Akhir pertemuan dilakukan evaluasi dan konsultasi bersamaan dengan pengisian biodata lengkap. Forum diskusi ini juga di hadiri unsur pimpinan desa, kecamatan dan masyarakat, tokoh agama, tokoh masyarakat, orang tua dan remaja.

Hasil dari pengabdian adanya peningkatan pemahaman dan pengetahuan hukum masyarakat tentang bentuk tindak pidana narkotika, modus tindak pidana narkotika, kebijakan hukum terhadap anak penyalahgunaan narkotika, serta peran kerjasama komponen masyarakat dalam pencegahan tindak pidana dan dampaknya terhadap anak. Pada akhirnya terciptanya kekuatan peran masyarakat dalam mencegah tindak pidana narkotika di lingkungannya.
\end{abstract}

Kata Kunci: Pendidikan hukum, Pencegahan Tindak Pidana Narkotika, Anak 


\section{A. PENDAHULUAN}

Secara etimologi istilah narkotika berasal dari kata marke (Bahasa Yunani) yang berarti terbius sehingga menjadi coati rasa atau tidak merasakan apa-apa lagi.Narcotic adalah a drug that dulls the sense, relieves pain, induces sleep, and can produce addiction in varying degree ${ }^{l}$.

Menurut sistem hukum di Indonesia, penyalahgunaan narkotika dikualifikasikan kejahatan yang diatur dalam Undang-Undang No. 35 Tahun 2009 tentang Narkotika (UU Narkotika). Menurut UU ini, narkotika adalah zat atau obat yang berasal dari tanaman atau bukan dari tanaman, baik sintetis maupun semi sintetis yang dapat menyebabkan penurunan atau perubahan kesadaran, hilangnya rasa, mengurangi sampai menghilangkan rasa nyeri, dan dapat menimbulkan ketergantungan, pengolongannya diatur dalam UU dan keputusan Menteri Kesehatan. ${ }^{2}$

Narkotika disatu sisi merupakan obat atau bahan yang bermanfaat di bidang pengobatan, pelayanan kesehatan dan pengembangan ilmu pengetahuan, namun di sisi lain dapat menimbulkan ketergantungan yang sangat merugikan apabila dipergunakan tanpa adanya pengendalian, pengawasan yang ketat dan seksama.

Ketaatan masyarakat terhadap hukum disebabkan tiga hal yakni: (1) takut

${ }^{1}$ Soedarto, 1981, Kapita Selekta Hukum Pidana, Bandung, Penerbit Alumni, halaman 23.

${ }^{2}$ Lihat Pasal 1 Undang-Undang RI No. 35 tahun 2009 tentang Narkotika.

berbuat dosa; (2) takut karena kekuasaan dari pihak penguasa berkaitan dengan sifat hukum yang bersifat imperatif; (3) takut karena malu berbuat jahat. Penegakan hukum dengan sarana non penal mempunyai sasaran dan tujuan untuk kepentingan internalisasi. ${ }^{3}$

Narkotika adalah zat yang sangat berbahaya bagi tubuh manusia, jika dipergunakan tidak sesuai dengan dosis aturan yang telah ditetapkan. Masyarakat terkadang tidak mengetahui dampak negatif yang timbul dari pengunaan narkotika diantaranya akan menimbulkan ketergantungan, daya tahan tubuh berkurang, kemampuan intelektual berkurang, pemalas. Dampak negatif tersebut sangat berbahaya jika dibiarkan tetap bereda dalam masyarakat, terutama bagi generasi muda. Kondisi ini menyebabkan perkembangan negara di masa yang akan datang mengalami kemunduran. Selain efek tersebut perubahan perilaku akan timbul seiring dengan penggunaan zat tersebut seperti apatis, disphoria, agitasi regardasi psikomotor atau gangguan fungsi social.Setelah digunakan sekian lama dan pengguna kemudian tidak ingin lagi menggunakannya bukan hal yang mudah dilewati karena pengguna tersebut harus menghadapi keram otot parah, nyeri

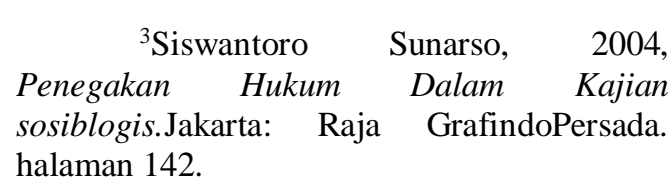


Marlina. et al. Pendidikan Hukum Pencegahan Tindak Pidana Narkotika Dan Dampak ...

tulang, diare, keram perut, rhinorea laksimasiphiloereksi, demam, dilatasi pupil, hypertensitakicardia, disregulasi, pipothermia dan hipethermin ${ }^{4}$.

Bentuk - bentuk kejahatan tindak pidana penyalahgunaan Narkotika yang umum di kenal antara lain berikut ini.

1. Penyalahgunaan Narkotika atau melebihi dosis. Hal ini dapat disebabkan oleh berbagai hal seperti yang telah di utarakan diatas.

2. Peredaran Narkotika bagi orang-orang yang tanpa haknya seperti adanya keterkaitan dengan sesuatu organisasi atau mata rantai peredaran gelap Narkotika yang tanpa haknya di tingkatNasional maupun Internasional.

3. Jual beli bagi orang-orang yang tanpa haknya dan perbuatan tersebut adalah perbuatan yang melawan hukum menurut Undang - undang RI No 35 Tahun 2009 tentang Narkotika, dimana pada umumnya dilatarbelakangi oleh motivasi untuk mencari keuntungan materil yang besar; tetapi ada juga karena motivasi untuk kepuasan diri sendiri.

Ketiga bentuk kejahatan tindak pidanaNarkotika tersebut dapat menjadi penyebab terjadinya berbagai macam bentuk tindak pidana kejahatan dan pelanggaran yang secara langsung mengakibatkan demoralisasi dalam

${ }^{4}$ A R Sudjono dan Bony Daniel Komentar dan Pembahasan Undang Undang RI No 35 Tahun 2009 tentang Narkotika, Jakarta Sinar Grafika,2013. masyarakat terutama untuk generasi muda sebagai pengguna dapat melakukan kejahatan seperti :
a. Tindak pidana Pembunuhan
b. Tindak pidana Pencurian
c. Tindak pidana Perampokan
d. Tindak pidana Pemerasan
e. Tindak pidana Pemerkosaan
f. Tindak pidana Penipuan
g. Pelanggaran Lalu Lintas

h. Dan lain - lain

Penggolongan Narkotika didalam Undang - undang No 35 Tahun 2009 adalah

1. Narkotika golongan I adalah Narkotika yang hanya dapat digunakan untuk tujuan pengembangan Ilmu Pengetahuan dan tidak digunakan dalam therapi pengobatan serta mempunyai potensi tinggi mengakibatkan ketergantungan

2. Narkotika golongan II adalah Narkotika yang berkhasiat untuk pengobatan dan digunakan sebagai pilihan terakhir dan dapat digunakan dalam therapy dan atau untuk tujuan pengembangan Ilmu Pengetahuan serta mempunyai potensi mengakibatkan ketergantungan.

3. Narkotika golongan III adalah Narkotika yang berkhasiat untuk pengobatan dan banyak digunakan dalam therapy dan atau untuk tujuan pengembangan Ilmu

${ }^{5}$ MTaufik Makaraodkk, 2003, Tindak Pidana Narkotika, Jakarta Ghalia Indonesia 2003, halaman 45. 
Marlina. et al. Pendidikan Hukum Pencegahan Tindak Pidana Narkotika Dan Dampak ...

Pengetahuan serta mempunyai potensi ringan dan mengakibatkan ketergantungan ${ }^{6}$ Efek pengaruh Narkotika bagi tubuh diantaranya mempengaruhi kesadaran, memberikan dorongan yang dapat berpengaruh terhadap perilaku manusia dan munculnya pengaruh-pengaruh berupa penenang, perangsang dan menimbulkan halusinasi. Selain itu Narkotika juga memimbulkan efek diantaranya:

a. Depresant yaitu mengendurkan atau mengurangi aktivitas atau kegiatan susunan syaraf pusat sehingga dipergunakan untuk menenangkan syaraf seseorang untuk dapat tidur atau istirahat.

b. Stimulant yaitu meningkatkan keaktifan susunan syaraf pusat sehingga merangsang dan meningkatkan kemampuan fisik seseorang.

c. Halusinogen yaitu menimbulkan perasaan-perasaan yang tidak riel atau khayalan- khayalan yang menyenangkan .

d. Rusaknya susunan-susunan syaraf pusat, rusaknya organ tubuh seperti Hati dan Ginjal

e. Timbulnya penyakit kulit seperti bintikbintik merah pada kulit, kudis dan sebagainya

f. Lemah fisik, moral dan daya fikir.

g. Timbulnya kecenderungan melakukan penyimpangan sosial dalam masyarakat

${ }^{6}$ Bambang Hartono, Implementasi Kebijakan Polri terhadap pelaku, pengguna sabu- sabu dibawah 1 Gram , Jurnal Hukum diakses tanggal 20 Desember 2016. seperti berbohong, berkelahi, free sex dan lain sebagainya.

h. Timbulnya kegiatan atau aktivitas dis social seperti mencuri, menodong, merampok dan sebagainya untuk mendapatkan uang guna membeli Narkotika yang jumlah dosisnya semakin tinggi. ${ }^{7}$

Maraknya tindak pidana yang melibatkan anak-anak membutuhkan perhatian semua pihak. Penyimpangan tingkah laku atau perbuatan melanggar hukum yang dilakukan oleh anak disebabkan oleh berbagai faktor, antara lain adanya dampak negatif dari perkembangan informasi, arus globalisasi di bidang komunikasi dan informasi serta perubahan gaya dan cara hidup sebagian orang tua telah membawa perubahaana sosial yang mendasar dalam kehidupan masyarakat yang sangat berpengaruh terhadap nilai dan prilaku anak. ${ }^{8}$ Selain itu anak yang kurang atau tidak memperoleh kasih sayang, asupan bimbingan dan pembinaan dalam pengembangan sikap, prilaku penyesuai diri serta pengawasan dari orang tua wali, atau orang tua asuh dan pergaulan lingkungan masyarakat yang kurang sehat juga menyebabkan seseorang anak dapat terjerumus dalam kejahatan. ${ }^{9}$

${ }^{7}$ Ibid.

${ }^{8}$ Adi Kusno, 2009, kebijakan kriminal dalam penanggulangan tindak pidana narkotika oleh anak, Malang, UMM Press, hal. 10.

${ }^{9}$ Ibid, hal. 11 
Marlina. et al. Pendidikan Hukum Pencegahan Tindak Pidana Narkotika Dan Dampak ...

Desa salam Tani dan desa Tengah adalah sebuah desa yang letaknya di Kecamatan Pancur Batu Kabupaten Deli Serdang Sumatera Utara, yang memiliki keragaman penduduk, agama yang ada di desa tersebut Kristen, Islam, Budha dan Hindu, Pendudukan rata-rata memiliki pekerjaan bertani dan berladang serta berdagang. Suku yang ada di daerah ini suku Karo, Batak, Jawa dan Minang, bahkan di desa tersebut ada penduduk keturunan Cina. Kehidupan masyarakatnya sangat komplek sekali. Tingkat Pendidikan di kedua desa ini bisa dikategorikan masih dikategorikan rendah, karena perhatian dan keinginan memajukan anak ke tingkat pendidikan yang lebih tinggi masih kurang. Hetrogennya penduduk, dan kompleknya mata pencaharian dan kegiatan masyarakat di dua desa menyebabkan kompleksnya juga permasalahan yang ada di desa tersebut. Permasalahan yang dihadapi desa Salam Tani dan Desa Tengah adalah pengetahuan dan pemahaman tentang hukum sangat kurang, perhatian terhadap lingkungan keluarga dan lingkungan sosial masih sangat rendah. Kondisi ini menyebabkan adanya anak-anak yang di khawatirkan memiliki peluang yang besar untuk terlibat dalam tindak pidana narkotika dan dampak narkotika dalam perkembangan hidupnya.

Permasalahan Desa Salam Tani dan Desa tengah yang prioritas adalah maraknya peredaran narkotika dengan berbagai jenis saat ini dikhawatirkan masuh ke wilayah mitra, kurangnya kerjasama komponen masyarakat dalam pencegahan tindak pidana narkotika serta kurangnya pengetahuan dan pemahaman tentang narkotika, sanksi hukum narkotika, perbuatan apa yang dikategorikan sebagai tindak pidana narkotika serta dampak narkotika terhadap perkembangan anak di masa depan. Permasalah lainnya terkait dengan kebijakan dalam pencegahan tindak pidana narkotika yang dilakukan oleh pihak pemerintahan desa.

Berdasarkan pendekatan awal dengan pihak Mitra. Ahkirnya Tim pengabdian masyarakat USU mendapatkan kesempatan untuk memberikan pendidikan hukum pencegahan tindak pidana narkotika dan dampak narkotika terhadap anak di desa mitra. Adapun yang menjadi permasalahan dalam kegiatan ini antara lain adalah sebagai berikut:

1. Apakah faktor penyebab anak-anak terlibat tindak pidana narkotika ?

2. Bagaimanakah pengaturan hukum tindak pidana narkotika di Indonesia?

3. Apakah dampak pengunaan narkotika terhadap anak dalam perkembangan pendidikannnya?

4. Bagaimana kerjasama komponen masyarakat dalam pencegahan tindak pidana narkotika terhadap anak?

5. Bagaimana kebijakan pemerintahan desa dalam upaya pencegahan tindak pidanan narkotika terhadap anak? 
Marlina. et al. Pendidikan Hukum Pencegahan Tindak Pidana Narkotika Dan Dampak ...

\section{B. Metode Pengabdian}

Mitra dalam program ini adalah desa Salam Tani Kecamatan Pancur Batu dan Desa Tengah Kecamatan Pancur Batu Metode yang digunakan pendekatan secara persuasif in formal lalu di lanjutkan dengan pertemuan formal untuk diberikan penyuluhan secara menyeluruh selanjutnya diadakan diskusi dan pendampingan terhadap permasalahan narkotika yang terjadi dalam masyarkat sehingga ditemukan solusi pemeca. hannya dan upaya pencegahan. Selain daripada itu kegiatan sosialisasi ini juga memakai beberapa alat bantu yaitu berupa pemberian buku panduan mengenai Tindak Pidana Narkotika dan Upaya Pencagahan serta dampak Narkotika terhadap anak, laptop, in focus, penggandaan bahan dan undang-undang No.35 tahun 2009 Tentang Narkotika dan peraturan pelaksananya. Secara khusus target dan luaran dari kegiatan pengabdian ini adalah buku panduan, kelompok binaan, Artikel terkait upaya pencegahan tindak pidana narkotika dan dampak terhadap anak.

\section{Hasil Pengabdian}

Pengabdian yang dilakukan di dua desa mitra yaitu Desa Salam Tani dan Desa Tengah sejak bulan Agustus sampai dengan bulan Oktober. Pada tangal 13-14 September pertemuan formal masyarakt di Desa Salam /tani yang terlibat 40 orang sebagai peserta aktif dan responsif materi yang dilakukan, selanjutnya peserta inilah yang kemudia harus terus dilakukan upaya pertemua dan kontak untuk komunikasi begitu juga di Desa tengah ada 40 peserta aktif yang ikut berpartisifasi. Saat pertemuan formal dilakukan peserta dibagikan buku panduan sebagai pegangan untuk memahami tentang tindak pidana narkotika dan upaya pencegahannya.

Kegiatan ini diawali dengan pembukaan oleh tim penyuluh, kemudian dilanjutkan dengan kata sambutan dari Kepala Desa Salam Tani Kecamatan Pancur Batu. Kata sambutan kepala desa mengatakan bahwa tim pengabdian ini akan mengadakan pengabdian di desa kita untuk memahami tentang tindak pidana narkotika dan dampak hukumnya sedta bagaiman upaya pencegahannya, tim akan bekerja selama 3 bulan lebih yang nantinya akan mengadakan pertemuan formal dan informal kepada kita semua mohon semua warga membantunya.

Pertemuan yang diadakan tanggal 5-6 September di Desa Salam Tani dan 1516 September di desa Tengah. dilakukan pertemuan dengan membagikan buku pandua yang telah dibuat berdasarkan hasil penelitian pendahuluan yang dilakukan kepada masyarakat. Buku ini berisikan mengenai faktor anak terlibat narkotika, dampak narkotika dan sanksi pidana terhadap tindak pidana narkotika. Acara dilanjutkan dengan penyampaian materi oleh tim penyuluh. Peserta sangat antusia memperhatikan penyampaian materi yang dilakukan tim pemateri. Selanjutnya 
Marlina. et al. Pendidikan Hukum Pencegahan Tindak Pidana Narkotika Dan Dampak ...

dilakukan sesi tanya jawab dan diskusi.

Peserta sangat antusias hal ini terlihat dari banyaknya pertanyaan yang dilontarkan peserta. Atas pertanyaan-pertanyaan yang diajukan peserta tim pelatihan berupaya memberikan penjelasan secara tuntas sehingga peserta memahami dan merasa puas atas jawaban dan penjelasan yang diberikan. Peserta juga memberikan masukan terkait dengan buku pedoman yang diberikan.

Adapun materi yang disampaikan dalam paparan dan buku pedoman sebagai berikut:

\section{A. Pengertian Narkotika}

Narkotika berasal dari bahasa
Yunani "narke" yang berarti terbius
sehingga tidak merasakan apa-apa. ${ }^{10}$

Kemudian menggunakan istilah narkotikos yang berarti kaku seperti patung atau tidur. Lama-kelamaan perkataan narkotikos mengalami perubahan makna. Dahulu kata itu berarti tidur atau patung kemudian berubah-ubah makna menjadi zat atau bahan yang dapat membantu orang untuk dapat tenang tidur.

Menurut Pasal 1 angka 1 Narkotika adalah zat atau obat yang berasal dari tanaman atau bukan tanaman, baik sintetis maupun semisintetis, yang dapat menyebabkan penurunan atau perubahan kesadaran, hilangnya rasa, mengurangi sampai menghilangkan rasa

10 B. Bosu, Sendi-Sendi Kriminologi, (Surabaya: Usaha Nasional, 1982), Halaman 86. nyeri, dan dapat menimbulkan ketergantungan, yang dibedakan ke dalam golongan-golongan sebagaimana terlampir dalam Undang-Undang ini.

Tujuan pembentukan UU NO. 35 Tahun 2009 yaitu:

1. Menjamin ketersedianya narkotika untuk kepentingan pelayanan kesehantan dan atau pengembangan ilmu pengetahuan dn teknologi

2. Mencegah, melindungi dn menyelamatkan bangsa indonesia dari penyalahgunaan narkotika

3. Memberantas peredaran gelap narkotika dan prekusor narkotika dan

4. Menjamin pengaturan upaya rehabilitasi medis dan sosial bagi penyalahguna dan pencandu narkotika. ${ }^{11}$

Pemerintah mengeluarkan peraturan dan perundang-undangan untuk mengatasi permasalahan tersebut, diantaranya yang terbaru adalah Undang-Undang RI Nomor 35 Tahun 2009. Sebelumnya Mahkamah Agung mengeluarkan Surat Edaran Nomor: 07 Tahun 2009 tentang menempatkan pemakai narkoba ke dalam panti terapi dan rehabilitasi. Surat edaran Mahkamah Agung disebutkan pada ayat 4 bahwa:

Dalam hal hakim menjatuhkan pemidanaan berupa perintah untuk dilakukan tindakan hukum berupa rehabilitasi atas diri

${ }^{11}$ Azia Syamsudin, Tindak Pidana Khusus, Sinar grafika, 2011, Jakarta, hal. 89 
Marlina. et al. Pendidikan Hukum Pencegahan Tindak Pidana Narkotika Dan Dampak ...

Terdakwa, Majelis harus menunjuk secara tegas dan jelas tempat rehabilitasi yang terdekat, dalam amar putusannya tempattempat rehabilitasi dimaksud adalah :

a) Unit Pelaksana Teknis T \& R BNN Lido Bogor.

b) Rumah sakit Ketergantungan Obat, Cibubur Jakarta dan di seluruh Indonesia (Depkes RI).

c) Panti Rehabilitasi Depsos RI dan UPTD.

d) Rumah Sakit Jiwa di seluruh Indonesia; atau

e) Tempat rujukan panti rehabilitasi yang diselenggarakan oleh masyarakat yang mendapat akreditasi dari Departemen Kesehatan atau Departemen Sosial (dengan biaya sendiri)

\section{B. Faktor Penyebab Penyalahguna Narkotika:}

1. Faktor individu, ${ }^{12}$ yang mudah kecemasan atau depresi.

2. Faktor sosial budaya, terdiri dari kondisi keluarga dan pengaruh pergaulan.

3. Faktor lingkungan, yang tidak baik maupun tidak mendukung dalam menampung segala sesuatu yang menyangkut perkembangan psikologis anak dan kurangnya perhatian terhadap anak untuk menjadi pemakai narkotika.

4. Faktor narkotika, seperti maraknya perdaran narkotikan dan peredaran

\footnotetext{
12 Chazawi Adami, Pelajaran Hukum
} Pidana I, Jakarta : Rajawali Press, 2008. Halaman 30 narkotika yang memasuki semua lini kehidupan dan berada dalam semua situasi dan kondisi lingkungan masyarakat saat ini, menyebabkan anak mula sekali mendapatkan narkotika dan menyalahgunakan narkotika.

\section{Ciri Penguna Narkotika}

Menurut riset Badan Narkotika Nasional (BNN) berdasarkan wawancara BNN dengan para pecandu narkoba ditemuka ada 53 ciri pengguna narkoba ${ }^{13}$ diantaranya : jika diajak bicara jarang mau kontak mata, Bicara pelo/cadel, Jika keluar rumah sembunyi-sembunyi, Keras kepala/susah dinasehati, Sering menyalahkan orang lain untuk kesalahan yang dia buat, Tidak konsisten dalam berbicara (mencla-mencle),Sering mengemukan alasan yang dibuat-buat, Sering berbohong, Sering mengancam, menantang atau sesuatu hal yang dapat menimbulkan kontak fisik atau perkelahian untuk mencapai keinginannya, Berbicara kasar kepada orang tua atau anggota keluarganya, Semakin jarang mengikuti kegiatan keluarga, Berubah teman dan jarang mau mengenalkan teman-temannya, Teman sebayanya makin lama tampak mempunyai pengaruh negatif, lalai tanggung jawab, sering dihukum atau dimarahi, makin menjadi-jadi dengan menunjukan sifat membangkang jika di marahi, Tidak mau mepedulikan peraturan

\footnotetext{
${ }^{13}$ www.bnn.go.id
} 
Marlina. et al. Pendidikan Hukum Pencegahan Tindak Pidana Narkotika Dan Dampak ...

di lingkungan keluarga, Sering pulang lewat larut malam, Sering pergi ke diskotek, mal atau pesta, Menghabiskan uang tabungannya atau selalu kehabisan uang, Barang-barang berharga miliknya atau milik keluarga yang dipinjam hilang dan sering tidak dilaporkan dan maksa minta uang, ingin bebas, suka menyendiri, di kamar sendiri atau kamar mandi, Jarang mau makan atau berkumpul bersama keluarga, Sikapnya manipulatif, Emosi tidak stabil atau naik turun, Berani berbuat kekerasan atau kriminal, Ada obat-obatan, kertas timah, bong (botol yang ada penghisapnya) maupun barang-barang aneh lainnya (aluminium foil, jarum suntik, gulungan uang/kertas, dll), baubauan yang tidak biasa (di kamar tidur atau kamar mandi), Sering makan permen karet atau permen mentol untuk menghilangkan bau mulut, dan sebagainya.

Pencandu tidak dapat mengendalikan diri untuk berhenti begitu saja, sehingga menghilangkan kontrol sosialnya. Keadaan seperti ini membuat pencandu siap melakukan apa saja untuk mendapatkan narkotika. Inilah yang membentuk karakteristik para pemakai narkotika. ${ }^{14}$ Menteri kesehatan dalam Surat Keputusan Menteri Kesehatan Republik Indonesia Nomor 422/menkes/SK/III/2010 tentang Pedoman Penatalaksanaan Medik Gangguan Penggunaan Napza,

14 www. Elib.unikom.ac.id, jenis-jenis narkoba dan sifat penggunanya, diakses 472012 memberikan gambaran bagaimana karakteristik/parameter seorang pecandu narkotika yang dapat disimpulkan bahwa seseorang penyalahguna narkotika dapat dikatakan sebagai pecandu narkotika adalah seseorang yang memiliki ciri sebagai berikut: ${ }^{15}$

a. Ciri pecandu narkotika secara umum:

Suka berbohong, Delusive (tidak biasa membedakan dunia nyata dan khayal), Cenderung malas, Cendrung vandalistis (merusak), Tidak memiliki rasa tanggung jawab, Tidak bisa mengontrol emosi dan mudah terpengaruh terutama untuk hal hal yang negatif.

b. Gejala dan ciri - ciri seorang pecandu narkotika secara fisik diantaranya Pusing / sakit kepala, Berat badan menurun, malnutrisi, penurunan kekebalan, lemah, Mata terlihat cekung dan merah, muka pucat, dan bibir kehitam-hitaman, Bicara cadel, Mual, Badan panas dingin, Sakit pada tulang- tulang dan persendian, Sakit hampir pada seluruh bagian badan.

c. Ciri - ciri pecandu narkoba secara psikologis berhalusinasi, Paranoid, Ketakutan pada bentuk-bentuk tertentu dan histeria.

15 Lihat Lampiran Surat Keputusan Menteri Kesehatan Republik Indonesia Nomor Permenkes/sk/iii/2010 tentang Pedoman Penatalaksanaan Medik Gangguan Penggunaan Napza 


\section{Pelaku Tindak Pidana}

Pelaku tindak pidana itu ada pelaku yang tunggal melakukan tindak pidana ada juga yang bersama-sama melakukan tindak pidana dalam kata penyertaan (Deelneming). Menurut Teguh Prasetyo Ajaran penyertaan tindak pidana berpokok pada menentukan pertanggungjawaban peserta terhadap tindak pidana yang telah dilakukan, disamping itu juga mempersoalkan peranan atau hubungan tiap-tiap peserta dalam suatu pelaksanaan tindak pidana mengenai sumbangan atau peran apa yang telah diberikan tiap-tiap peserta agar tindak pidana tersebut dapat diselesaikan. ${ }^{16}$ Penyertaan dapat dibagi menurut sifatnya, yakni: penyertaan berdiri sendiri dan penyertaan yang tidak berdiri sendiri. Penyertaan diatur dalam Pasal 55 dan Pasal 56 KUHP, berdasarkan pasalpasal tersebut panyertaan dibagi menjadi dua pembagian besar, yaitu : pembuat (dader), menyuruh melakukan (doenlpeger), turut serta (medepleger), dan penganjur (uitlokker). Pembantu/Medeplichtige (Pasal 56 KUHP) yang terdiri dari pembantu pada saat kejahatan dilakukan dan pembantu sebelum kejahatan dilakukan. Untuk ditentukan adanya suatu keturutsertaan adalah diisyaratkatkan adanya kerjasama

${ }^{16}$ Andi, Hamzah 1996, Bunga Rampai Hukum Pidana dan Acara Pidana, Jakarta: halaman 49 antara para pelaku yang disadari, dan kesengajaan untukkerjasama itu harus dapat dibuktikan. Adapun syarat-syarat adanya medepleger adalah:

a. Ada kerja sama secara sadar dalam melakukan tindakpidana.

b. Tujuan kerjasama ini bertujuan kepada hal yang dilarangUndang-Undang.

c. Pelaksanaannya bersama secara fisik sehingga suatu perbuatan pidana terselesaikan/sempurna.

E. Tindak Pidana Penyalahgunaan Narkotika

Kebijakan Pidana dan Pemidanaan dalam Undang-Undang Nomor 35 Tahun 2009, yang diatur mulai Pasal 111 s.d. Pasal 148, yang mengatur tentang perbuatan-perbuatan tanpa hak dan melawan hukum, yakni:

a. Tindak pidana yang berkaitan dengan penggolongan narkotika, dan prekursor narkotika, meliputi:

1) Menanam, memelihara, meimiliki, menyimpan, menguasai, menyediakan narkotika golongan I, II, dan golongan III baik dalam bentuk tanaman dan bukan tanaman;

2) Pengadaan dan peredaran narkotika golongan I, II, dan golongan III, yang tidak menaati ketentuan perundangundang yang berlaku, seperti:

a) Memproduksi, mengimpor, mengekspor, atau menyalurkan 
narkotika golongan I, narkotika golongan II, narkotika golongan III;

b) Menawarkan untuk dijual, menjual, membeli, menerima, menjadi perantara dalam jual beli, menukar, atau menyerahkan narkotika golongan I, narkotika golongan II, narkotika golongan III;

c) Membawa, mengirim, mengangkut, atau mentransit narkotika golongan I, narkotika golongan II, narkotika golongan III;

d) Menggunakan narkotika golongan I terhadap orang lain, atau memberikan narkotika untuk digunakan orang lain, narkotika golongan I, golongan II, narkotika golongan III;

e) Setiap penyalahguna narkotika golongan I, golongan II, dan golongan III bagi diri sendiri;

f) Orang tua atau wali dan pecandu yang belum cukup umur yang sengaja tidak melapor atau setiap orang yang dengan sengaja tidak melaporkan adanya tindak pidana Pasal 111

s.d. Pasal 129;

g) Dalam hal tindak pidana dalam Pasal 111 s.d. Pasal 126, dan Pasal 129 yang dilakukan oleh korporasi, atau dilakukan secara terorganisasi,

h) Membujuk anak yang belum cukup umur untuk melakukan tindak pidana dalam Pasal 111 s.d. Pasal 126 dan Pasal 129 undang-undang ini; i) Pecandu narkotika yang sudah cukup umur dan dengan sengaja tidak melaporkan diri atau keluarga dan pecandu narkotika yang dengan sengaja tidak melaporkan pecandu narkotika tersebut

j) Tindak pidana narkotika yang dilakukan oleh para pejabat yang berkaitan dengan narkotika, meliputi:

1) Pengurus industri farmasi yang tidak melaksanakan kewajiban dalam Pasal 45;

2) Pimpinan rumah sakit, pusat kesehatan masyarakat, balai pengobatan sarana penyimpanan sediaan farmasi milik pemerintah dan apotek yang mengedar narkotika golongan II dan III bukan untuk kepentingan pelayanan kesehatan;

3) Pimpinan lembaga ilmu pengetahuan yang menanam, membeli, menyimpan atau menguasai tanaman narkotika bukan untuk kepentingan pengembangan ilmu pengetahuan;

4) Pimpinan industri farmasi tertentu yang memproduksi narkotika golongan I bukan untuk kepentingan pengembangan ilmu pengetahuan, atau

5) Pimpinan pedagang besar farmasi yang mengedarkan narkotika golongan I yaitu bukan untuk kepentingan pengembangan ilmu pengetahuan atau

6) Mengedarkan narkotika golongan II dan III, bukan untuk kepentingan pelayanan kesehatan dan/atau bukan untuk 
Marlina. et al. Pendidikan Hukum Pencegahan Tindak Pidana Narkotika Dan Dampak ...

kepentingan pengembanga ilmu pengetahuan;

7) Nakhoda atau kapten penerbang yang secara melawan hukum tidak melaksanakan ketentuan dalam Pasal 27 atau Pasal 28;

8) Penyidik Pegawai Negeri Sipil yang secara melawan hukum tidak melaksanakan ketentuan dalam Pasal 88 dan Pasal 89;

9) Penyidik Kepolisian Negara Republik Indonesia dan Penyidik BNN yang tidak melaksanakan ketentuan dalam Pasal 87, Pasal 89, Pasal 90, Pasal 91 Ayat (2) dan Ayat (3), dan Pasal 92 Ayat (1), Ayat (2), Ayat (3) dan Ayat (4);

10). Kepala Kejaksaan Negeri yang secara melawan hukum tidak melaksanakan ketentuan dalam Pasal 91 Ayat (1) dipidana penjara dan pidana denda;

11). Petugas laboratorium yang memalsukan hasil pengujian atau secara melawan hukum tidak melaksan akan kewajiban melaporkan hasil pengujiannya kepada penyidik atau penuntut umum, dipidana dengan pidana penjara dan pidana denda;

k. Ketentuan lain dalam rangka pemeriksaan terhadap tindak pidana Narkotika, meliputi:

1. Percobaan atau permufakatan jahat untuk melakukan tindak pidana narkotika dan prekursor narkotika dalam Pasal 111 s.d. Pasal 126 dan Pasal 129;
2. Pemberatan pidana tersebut tidak berlaku bagi tindak pidana yang diancam dengan pidana mati, pidana penjara seumur hidup atau pidana penjara 20 tahun;

3. Menghalang-halangi atau mempersulit penyidikan serta penuntutan dan pemeriksaan perkara tindak pidana narkotika dan/atau tindak pidana prekursor narkotika di muka sidang pengadilan;

4. Narkotika dan prekursor narkotika serta hasil-hasil yang diperoleh dan tindak pidana narkotika dan/atau tindak pidana prekursor narkotika, baik berupa aset dalam bentuk benda bergerak maupun tidak bergerak, berwujud atau tidak berwujud serta barang-barang atau peralatan yang digunakan untuk melakukan tindak pidana narkotika dan tindak pidana prekursor narkotika dirampas untuk negara;

5. Saksi yang memberi keterangan tidak benar dalam pemeriksaan perkara tindak pidana narkotika dan prekursor narkotika di muka pengadilan dipidana dengan pidana penjara dan pidana denda;

6. Apabila pidana denda tidak dapat dibayar oleh pelaku tindak pidana narkotika dan tindak pidana prekursor narkotika, pelaku dijatuhi pidana penjara paling lama dua tahun sebagai pengganti pidana denda yang tidak dapat dibayar; 
7. Setiap orang yang dalam jangka waktu tiga tahun melakukan pengulangan tindak pidana narkotika dalam Pasal 111 s.d. Pasal 129 pidana maksimumnya ditambah dengan sepertiga.

\section{F. Upaya Pencegahan}

1. Pentingnya pengawasan dari orang tua dan masyarakat untuk mencegah anak sebagai pencandu tindak pelaku tindak pidana dengan memperhatikan ciri-ciri fisik dan psikis anak yang tercandu narkotika.

2. Adanya Pengawasan (kontrol) kegiatan bermain anak-anak dan teman sepermainan anak tersebut.

3. Peningkatan kegiatan keagamaan dan kegiatan olah raga di desa sebagai tempat untuk menampung aspirasi dan kreatifitas anak.

4. Adanya kerjasama antara unsur pemerintahan desa, kecamatan dan pemuka masyarakat dan masyarakat dalam upaya pengawasan dan tindakan terhadap kegiatan anak dilingkungan masyarakat.

5. Adanya kebijakan untuk pencegahan tindak pidana narkotika dan dampak narkotika terhadap anak saat ini dan masa akan dating yang dibuat oleh pemerintahan kecamatan dan kabupaten dengan pembentukan relawan anti narkoba.
6. Peningkatan partisifasi dari aparat penegak hukum untuk secara aktif dan perseuasif melalui babinkatifmasnya untuk menjadi kontrol dalam pencegahan tindak pidana narkotika.

\section{Kesimpulan}

Narkotika telah beredar dengan cepat di dalam masyarakat oleh karena itu masyarakat harus melakukan berbagai upaya pencegahan kepada keluarga, adik atau anak, saudara agar tidak menjadi penyalaguna narkotika, pencandu atau pengedar narkotika. Sanksi hukum yang berat dalam UU narkotika menjadi satu bentuk upaya untuk menjerat para pelaku tindak pidana narkotika. Upaya yang dilakukan untuk mencegah tindak pidana narkotika adalah mengingkatkan peran serta masyarkaat, keluarga, orang tua dan aparat penegak hukum untuk melakukan tindakan pengawasan (kontrol) terhadap kegiatan yang ada di dalam masyarakat. Meningkatkan peran orang tua dan pemuka masyarakat dan tokoh agama untuk melakukan berbagai kegiatan dalam rangka pencegahan tindak pidana narkotika, melakukan gerakan aksi bersama tolak narkoba di lingkungan masyarakat dengan menjalin hubungan kerjasama yang kuat dan sistematis untuk proses penanggulangan dan pencegahan, seerta pemberantan tindka pidana narkotika di 
desa Salam Tani dan Desa tengah dapat berhail.

\section{Ucapan Terima Kasih}

Terima kasih kepada Lembaga Penelitian Pengabdian pada Masyarakat Universitas Sumatera Utara atas pendanaan pengabdian ini berdasarkan kontrak Perjanjian Penugasan Pelaksanaan Pengabdian Kepada Masyaraka Program Mono Tahun Tahun Anggaran 2017 Nomor: $\quad 3224 / U N 5.2 .3 .2 .1 / \mathrm{PPM} / 2017$, Tanggal 24 Juli 2017. PENDIDIKAN HUKUM PENCEGAHAN TINDAK PIDANA NARKOTIKA DAN DAMPAK NARKOTIKA TERHADAP ANAK

\section{DAFTAR PUSTAKA}

Adami, Chazawi, Pelajaran Hukum Pidana

I, Jakarta : Rajawali Press, 2008.

Atmasasmita, Romli (1997), Tindak Pidana Narkotika Transnasional dalam Sistem Hukum Pidana Indonesia, Bandung, Citra Aditya Bakti,

B. Bosu, Sendi-Sendi Kriminologi, (Surabaya: Usaha Nasional, 1982).

Chazawi Adami, Pelajaran Hukum Pidana

I, Jakarta : Rajawali Press, 2008

Hamzah, Andi, 1986, Bunga Rampai Hukum Pidana dan Acara Pidana, Jakarta.

Moeljatno, 2009, Kitab Undang-Undang Hukum Pidana, Jakarta; Bumi Aksara.

Kusno, Adi, 2009, kebijakan kriminal dalam penanggulangan tindak pidana narkotika oleh anak, Malang, UMM Press.

Ridwan, Halim, Hukum Pidana dalam

Tanya Jawab, Bandung : Alumni, 1986

Syamsudin, Azia, Tindak Pidana Khusus,

Sinar Grafika, 2011, Jakarta.

Surat Edaran Mahkamah Agung Nomor 07 Tahun 2009 tentang menempatkan pemakai narkoba ke dalam Panti Terapi dan Rehabilitasi.

Simorangkir, Rudy, Prasetyo, 2007, Kamus

Hukum, Jakarta: Sinar Grafika.

Sujono dan Daniel Bony, 2013, Komentar \& Pembahasan Undang-Undang Nomor 35 Tahun 2009 Tentang Narkotika, Jakarta: Sinar Grafika.

Supramono, Gatot, 2009, Hukum Narkoba

Indonesia, Jakarta: Djambatan.

Sasangka, Hari, Narkotika dan Psikotropika Dalam Hukum Pidana, (Bandung: Mandar Maju, 2003)

Internet dan Perundang-Undangan:

www.bnn.go.id

www. Elib.unikom.ac.id, jenis-jenis narkoba dan sifat penggunanya, diakses 472012

Undang-Undang $\quad$ o. 35 Tahun 2009 Tentang Narkotika.

Lihat Lampiran Surat Keputusan Menteri Kesehatan Republik Indonesia Nomor Permenkes/sk/iii/2010 tentang Pedoman Penatalaksanaan Medik Gangguan Penggunaan Napza 